\title{
PERBANDINGAN HASIL BELAJAR BIOLOGI MELALUI MODEL PEMBELAJARAN KOOPERATIF TIPE MAKE A MATCH DAN THE POWER OF TWO PADA KONSEP SISTEM EKSKRESI SISWA KELAS XI IPA SMAN 1 SUNGGUMINASA MAKASSAR
}

\author{
Nurhikma Ramadhana ${ }^{1}$ \\ Muslimin Ibrahim ${ }^{2}$ \\ Rudiana Agustini \\ ${ }^{1}$ Dosen Universitas Sulawesi Barat \\ ${ }^{2}$ Dosen Pascasarjana Prodi Pendidikan Sains Universitas Negeri Surabaya \\ e-mail: ramabiologi@gmail.com
}

\begin{abstract}
The study aims at examming 1) the difference of cognitive leraning outcomes between students who were taught by using cooperative learning model of Make a Match type and the ones taught by using The Power of Two type, 2) the difference of affective learning outcomes between students who were taught by using cooperative learning model of Make a Match type and the ones taught by using the Power of Two type 3) the difference of psychomotor learning outcomes between students who were taught by using cooperative learning model Make a Match type and the ones taught by using The Power of Two type of grade XI students at SMAN 1 Sungguminasa Makassar. The study was a quasi-experiment research which employed the static group pretest posttest design. The study used the experiment group I by implementing cooperative learning model of Make a Match type and the experiment group II by implementing cooperative learning model of The Power of Two type. The instruments of the study were the test of learning outcomes to measure the cognitive learning outcomes, observation sheet to measure affective and psychomotor learning outcomes of the students. Data were analyzed using descriptive statistic analysis and inferential statistic analysis (uji $t \alpha=0,05$ ) supported by SPSS 17.0 for windows program. that the result using The Power of Two was higher than the one using The Power of Two.
\end{abstract}

Keywords: Cooperative comparison learning model of Make a Match, Cooperative learning model of The Power of Two, cognitive, affective, and psychomotor learning outcomes.

\begin{abstract}
Abstrak: Penelitian ini bertujuan untuk 1) Mengetahui perbedaan hasil belajar kognitif siswa dengan penerapan model pembelajaran kooperatif tipe Make a Match dengan kooperatif tipe The Power of Two pada siswa kelas XI SMAN. 1 Sungguminasa Makassar 2) Mengetahui perbedaan hasil belajar afektif siswa dengan penerapan model pembelajaran kooperatif tipe Make a Match dengan kooperatif tipe The Power of Two pada siswa kelas XI SMAN 1 Sungguminasa Makassar 3) Mengetahui perbedaan hasil belajar psikomotorik siswa dengan penerapan model pembelajaran kooperatif tipe Make a Match dengan The Power of Two pada siswa kelas XI SMAN 1 Sungguminasa Makassar. Jenis penelitian ini adalah quasi eksperimen dengan rancangan The static Group Pretest Posttest Design. Instrumen penelitian berupa Tes Hasil Belajar (THB) untuk mengukur hasil belajar kognitif, dan lembar observasi untuk mengukur hasil belajar afektif dan psikomotorik siswa. Data dianalisis statistik deskriptif dan inferensial (Uji t $\alpha$ =0,05) dengan bantuan program SPSS 17.0 for windows. Hasil penelitian ini menunjukkan bahwa 1) Hasil belajar kognitif siswa dengan penerapan model pembelajaran The Power of Two lebih tinggi dibandingkan dengan penerapan model pembelajaran kooperatif tipe Make a Match 2) Hasil belajar afektif siswa dengan penerapan model pembelajaran tipe Make a Match lebih tinggi dibandingkan dengan penerapan model pembelajaran kooperatif tipe The Power of Two 3) Hasil belajar psikomotorik siswa dengan penerapan model pembelajaran tipe Make a Match lebih tinggi dibandingkan dengan penerapan model pembelajaran kooperatif tipe The Power of Two.
\end{abstract}

Kata-kata kunci: Model perbandingan kooperatif, make a match dan the power of two, pada afektif, kognitif, psikomotorik.

\section{PENDAHULUAN}

Kurikulum 2013 memuat tentang Kompetensi Inti (KI) yang merupakan anak tangga yang harus ditapak peserta didik untuk sampai pada kompetensi lulusan disetiap jenjang pendidikan (Kemendikbud, 2013: 1). KI1 mencakup inti sikap spiritual. KI di jenjang SMA/MA terdiri atas empat kelompok, khususnya KI-2 tentang kompetensi inti sikap sosial, nKompetensi Inti (KI) di atas merupakan aspek karakter yang harus dimiliki siswa setelah lulus SMA. KI tersebut sejalan dengan makna dari gagasan $\mathrm{Ki}$ Hajar Dewantara yaitu karakter merupakan bagian integral yang sangat penting dalam pendidikan. Biologi merupakan bagian yang sangat penting dalam kehidupan. Pelajaran biologi mulai dipelajari pada tingkat menengah pertama, walaupun sebenarnya pada jenjang sebelumnya biologi sudah diberikan secara tersirat dalam materi yang tergabung dalam pelajaran Ilmu Pengetahuan Alam (IPA), 
terkadang sebagian siswa masih menganggap pelajaran biologi adalah mata pelajaran yang rumit, sehingga siswa menjadi malas dan tidak termotivasi untuk mempelajari pelajaran biologi.

Kualitas pembelajaran dapat dilihat dari segi proses dan dari segi hasil.Pembelajaran dikatakan berhasil dan berkualitas apabila seluruhnya atau setidak-tidaknya sebagian besar peserta didik disamping menunjukkan kegiatan belajar yang tinggi, semangat belajar yang besar, dan percaya pada diri sendiri. Proses pembelajaran dikatakan berhasil apabila terjadi perubahan perilaku yang positif pada diri peserta didik seluruhnya atau setidak-tidaknya sebagian besar. Lebih lanjut proses pembelajaran dikatakan berhasil dan berkualitas apabila masih merata, menghasilkan output yang banyak dan bermutu tinggi, serta sesuai dengan kebutuhan, perkembangan masyarakat dan pembangunan (Mulyasa, 2003).Usaha pencapaian tujuan belajar perlu diciptakan adanya sistem lingkungan belajar yang lebih kondusif melalui kegiatan pembelajaran. Tujuan belajar tertentu harus diciptakan sistem lingkungan belajar tertentu pula (Haling, 2007).

Belajar mempunyai tujuan dan sasaran yang dikemukakan oleh Haling (2007) yaitu: (a) Tujuannya mengubah tingkah laku kearah yang lebih berkualitas, (b) Sasarannya adalah tingkah laku penalaran (kognitif), keterampilan (psikomotorik), dan sikap (afektif). Sardiman (2004) mengemukakan bahwa pada dasarnya tujuan belajar terdapat tiga jenis yaitu: (a) untuk mendapatkan pengetahuan, yaitu suatu cara untuk mengembangkan kemampuan berpikir bagi anak untuk memperoleh pengetahuan dan kemampuan berpikir, (b) untuk penanaman konsep dan keterampilan, yaitu suatu cara belajar menghadapi dan menangani objek-objek secara fisik dan psikis (c) Pembentukan sikap, yaitu suatu kegiatan untuk menumbuhkan sikap mental dan perilaku anak. Tujuan pembelajaran yang direncanakan meliputi tiga ranah yakni aspek ranah kognitif, ranah afektif, dan ranah psikomotorik. Pengelompokan siswa tersebut di kelas dikenal dengan "model pembelajaran kooperatif" yang diharapkan dapat meningkatkan hasil belajar (kognitif, afektif, dan psikomotorik. Pembelajaran kooperatif merupakan suatu model pembelajaran yang digunakan untuk membantu siswa dengan siswa yang lain dalam mempelajari suatu materi. Pembelajaran kooperatif, siswa bekerjasama dalam kelompok kecil yang heterogen dari segi prestasi, jenis kelamin, dan suku untuk saling membantu dalam mencapai tujuan bersama (Slavin, 2010).

Materi pokok bahasan atau materi tertentu harus dipilih yang paling sesuai dengan tujuan yang akan dicapai. Memilih suatu model pembelajaran harus memiliki pertimbangan-pertimbangan, misalnya materi pelajaran, tingkat perkembangan kognitif siswa, dan sarana atau fasilitas yang tersedia sehingga tujuan pembelajaran yang telah ditetapkan dapat tercapai (Suprijono, 2009). Model pembelajaran kooperatif terdiri dari beberapa tipe yang bervariasi yang dapat diterapkan dalam proses pembelajaran, seperti NHT (Numbered Heads Together), STAD (Student Teams-Achievement Divisions), TGT( Teams games tournament), Jigsaw, TAI
(Team Assisted Individualization), Make a Match, Investigasi Kelompok, dan The Power of Two.

Kesempatan ini peneliti hanya akan menerapkan dua model pembelajaran kooperatif, yaitu model pembelajaran kooperatif tipe The Power of Two dan Make a Match. Kedua tipe ini sama-sama bekerja tim atau kelompok, yang di harapkan bisa menjadi solusi dalam pencapaian tujuan pembelajaran. Ini di dasari karena model ini merupakan tipe yang menyatukan kerjasama antara tim dan menyatukan kekuatan dalam memecahkan suatu masalah. Penelitian ini akan menggunakan dua model pembelajaran kooperatif yaitu model pembelajaran kooperatif tipe Make a Match dengan The Power of Two karena model pembelajaran ini masih kurang digunakan dalam proses pembelajaran biologi di sekolah-sekolah, materi yang akan peneliti ajarkan adalah materi sistem ekskresi, kaitannya dengan model pembelajaran ini karakteristik materi pelajaran biologi khususnya pada materi sistem ekskresi memiliki kesesuaian.

Materi sistem ekskresi ini mudah dipahami oleh siswa maka model pembelajaran kooperatif tipe Make a Match dan The Power of Two inilah siswa dapat mengkonstruksi pengetahuan mereka tentang konsep sistem ekskresi.Model pembelajaran kooperatif tipe Make a Match mempunyai salah satu keunggulan model ini adalah siswa mencari pasangan sambil belajar mengenai suatu konsep atau topik dalam suasana yang menyenangkan. Tipe Make a Match ini bertujuan untuk memperluas wawasan serta kecermatan siswa dalam menyelami suatu konsep sedangkan model pembelajaran kooperatif tipe The Power of Two berarti menggabungkan dua kepala dalam hal ini adalah membentuk kelompok kecil, yaitu masing-masing siswa berpasangan. Kegiatan ini dilakukan agar munculnya suatu sinergi yakni dua kepala lebih baik dari satu (Lie, 2004).

Kajian teori yang membahas tentang model pembelajaran kooperatif tipe Make a Match dan The Power of Two mempunyai kesamaan dalam hal memberi kesempatan kepada siswa untuk berpikir secara individu menemukan konsep dan saling bertukar pikiran pada saat berpasangan. Kedua model ini akan dibandingkan untuk mengetahui model manakah yang lebih tepat dalam pembelajaran biologi khususnya pada materi sistem ekskresi.

\section{METODE PENELITIAN}

Jenis penelitian ini adalah eksperimen semu (quasi experiment) yaitu memperhatikan beberapa variabel saja yakni hasil belajar siswa dalam hal ini hasil belajar kognitif, afektif dan psikomotorik siswa yang bertujuan untuk mengetahui perbandingan hasil belajar siswa kelas XI pada materi sistem ekskresi dengan penerapan model pembelajaran kooperatif tipe Make a Match dengan model pembelajaran kooperatif tipe The Power of Two. Penelitian ini diawali dengan refleksi awal yang dilakukan oleh peneliti mencari informasi dan mengetahui kondisi awal yang ada pada tempat yang akan dijadikan sebyek penelitian. Secara umum penelitian ini terdiri dari tiga langkah utama yaitu tahap, 
persiapan, tahap pelaksanaan, dan tahap pengumpulan data.

Langkah-langkah dalam penelitian ini adalah sebagai berikut.

\section{Tahap Persiapan}

berikut:

Persiapan penelitian dilakukan dengan kegiatan

a. Mengadakan observasi di lokasi penelitian dan menentukan dua kelas yang akan dijadikan objek penelitian dengan penerapan model pembelajaran kooperatif tipe Make a Match dan The Power of Two.

b. Menganalisis kurikulum untuk melihat standar kompetensi dan kompetensi dasar, sehingga tampak materi pelajaran yang akan diajarkan, yaitu pada pokok bahasan "Sistem ekskresi" dengan enam kali pertemuan. Empat kali pertemuan tatap muka dan dua kali pertemuan untuk evaluasi.

c. Mengembangkan silabus berdasarkan kompetensi dasar yang disesuaikan dengan materi yang akan diajarkan. Sebelum melaksanakan pembelajaran biologi melalui model pembelajaran kooperatif tipe Make a Match dan The Power of Two, terlebih dahulu dilakukan beberapa persiapan yaitu, mempersiapkan perangkat pembelajaran yang terdiri atas Rencana Pelaksanaan Pembelajaran (RPP), Buku Siswa (BS), Media Pembelajaran dan Lembar Kerja Siswa (LKS). Perangkat pembelajaran tersebut sesuai dengan model pembelajaran kooperatif tipe Make a Match dan The Power of Two, masing-masing dirancang untuk empat kali pertemuan tatap muka dan dua kali untuk evaluasinya.

d. Membuat instrumen penelitian yang terdiri atas Tes Hasil Belajar (THB) untuk penilaian hasil belajar kognitif siswa dan lembar observasi untuk penilaian afektif dan psikomotorik siswa.

e. Melakukan validasi terhadap perangkat dan instrumen yang digunakan pada penelitian.

f. Revisi.

\section{Tahap Pelaksanaan}

Pelaksanaan tindakan dalam penelitian ini terdiri dari enam kali pertemuan, 4 kali pertemuan tatap muka dan 2 kali pertemuan evaluasi (pretest dan posttest), dan setiap 1 kali pertemuan terdiri atas 2 jam pelajaran. Satu jam pelajaran selama 45 menit. Langkah-langkah kegiatan mengajar untuk kelas $\mathrm{XI}_{6}$ menggunakan model pembelajaran kooperatif tipe Make a Match dan kelas $\mathrm{XI}_{7}$ menggunakan model pembelajaran kooperatif tipe The Power of Two dapat dilihat pada lampiran RPP.

\section{A. Perangkat Pembelajaran}

Perangkat pembelajaran dalam penelitian yaitu, Silabus, Rencana Pelaksanaan Pembelajaran (RPP), Lembar Kegiatan Siswa (LKS) dan Buku Siswa (BS).

\section{Desain Penelitian}

Desain penelitian ini, yaitu perlakuan diberikan pada variabel bebas untuk menentukan pengaruh pada variabel terikat. Pada penelitian ini dua sampel masingmasing diberi perlakuan yang berbeda yaitu model pembelajaran kooperatif tipe Make a Match di kelas XI.6 dan model pembelajaran kooperatif tipe The Power of two di kelas XI.7, desain penelitian yang digunakan adalah The Static Group Pretest Posttest Design Untuk lebih jelasnya desain dalam penelitian ini dilihat pada Tabel 3.1.

Tabel 3.1 Desain Penelitian

\begin{tabular}{|c|c|c|}
\hline $\mathrm{O}_{1}$ & $\mathrm{X}_{1}$ & $\mathrm{O}_{2}$ \\
\hline $\mathrm{O}_{3}$ & $\mathrm{X}_{2}$ & $\mathrm{O}_{4}$ \\
\hline
\end{tabular}

(Sumber: Sugiyono, 2010)

\section{HASIL DAN DISKUSI}

hasil penelitian tentang hasil validasi penilaian perangkat pembelajaran dan hasil belajar (kognitif, afektif dan psikomotorik) siswa setelah penerapan model pembelajaran kooperatif tipe Make a Match dan The Power of Two yang telah disusun dan ditelaah kepada dosen ahli serta keseluruhan data yang diperoleh dari hasil penelitian ini dianalisis baik secara deskriptif maupun secara inferensial untuk menjawab pertanyaanpertanyaan penelitian yang terdapat pada rumusan masalah yang terdapat pada bab sebelumnya.

Penelitian ini dilakukan pada dua kelas eksperimen yakni pada siswa kelas $\mathrm{XI}_{6}$ dan $\mathrm{XI}_{7} \mathrm{SMA}$. Negeri 1 Sungguminasa Makassar, $\mathrm{XI}_{6}$ diajarkan dengan penerapan model pembelajaran kooperatif tipe Make a Match dan kelas $\mathrm{XI}_{7}$ diajarkan dengan penerapan model pembelajaran kooperatif tipe The Power of Two. Kedua kelas yang digunakan sebagai sampel penelitian ini merupakan kelas yang setara. Perangkat pembelajaran kooperatif tipe Make a Match dengan The Power Of Two yang telah di buat oleh peneliti meliputi Silabus, Rencana Pelaksanaan Pembelajaran, Lembar Kerja Siswa, Buku Siswa, Kartu Permainan, Instrumen penelitian soal pretes dan posttes hasil belajar siswa. Penelitian ini menggunakan tahap perencanaan dan pelaksanaan dan akhirnya di lakukan uji coba 2. Perangkat yang di telaah secara bertahap kepada dosen ahli seperti Silabus, RPP, LKS, buku siswa, dan kartu untuk mendapatkan saran dan perbaikan sehingga perangkat pembelajaran yang di susun layak untuk di gunakan dalam pembelajaran. Berikut hasil telaah perangkat pembelajaran make a match dan the power of two melalui model pembelajaran tipe kooperatif Analisis deskriptif digunakan untuk menganalisis data dengan cara mendeskripsikan atau menggambarkan data yang telah terkumpul, dan mendeskripsikan hasil belajar biologi yang diperoleh siswa terhadap penguasaan materi melalui gambaran karakteristik distribusi nilai pencapaian hasil belajar siswa dengan penerapan model pembelajaran kooperatif tipe Make a Match dan The Power of Two pada materi sistem ekskresi. Berdasarkan nilai hasil belajar kognitif yang diperoleh siswa sebelum (pretest) dan sesudah (posttest) penerapan model pembelajaran kooperatif tipe Make a Match dan The Power of Two mendeskripsikan hasil belajar biologi yang diperoleh siswa terhadap penguasaan materi melalui gambaran karakteristik distribusi nilai pencapaian hasil belajar siswa dengan penerapan model pembelajaran kooperatif tipe Make a Match dan The Power of Two pada materi sistem ekskresi. Berdasarkan nilai hasil belajar kognitif yang diperoleh siswa sebelum (pretest) dan sesudah (posttest) 
penerapan model pembelajaran kooperatif tipe Make a Match dan The Power of Two dapat dilihat pada Tabel 4.10 .

Apabila Tabel 4.10 ditampilkan dalam bentuk histogram, maka distribusi frekuensi dan persentase nilai pretest dan posttest model pembelajaran kooperatif tipe Make a Match dengan The Power of Two dapat dilihat pada Gambar 4.1 dan 4.2.Berdasarkan Gambar 4.1 dan Gambar 4.2 menunjukkan perbandingan hasil belajar siswa sebelum (pretest) dan sesudah (posttest) penerapan model pembelajaran kooperatif tipe Make a Match kelas $\mathrm{XI}_{6}$ SMA. Negeri 1 Sungguminasa. Nilai pretest siswa dengan penerapan model pembelajaran kooperatif tipe Make a Match dengan jumlah 40 siswa yakni tidak ada siswa pada kategori nilai sangat tinggi, 10 siswa berada pada kategori tinggi, dan pada kategori sedang terdapat 18 siswa, serta pada kategori rendah terdapat 8 siswa, dan sangat rendah 2 siswa. Nilai posttest hasil belajar siswa dengan penerapan model pembelajaran kooperatif tipe Make a Match yakni ada 15 siswa berada pada kategori sangat tinggi, pada kategori tinggi ada 24 siswa, pada kategori sedang tidak ada siswa yang berada pada kategori tersebut, pada kategori rendah sebanyak 1 siswa, sedangkan pada ketegori sangat rendah tidak ada siswa yang berada pada kategori tersebut.

Berdasarkan Tabel 4.1 dan Gambar 4.2 menunjukkan perbandingan nilai pretest dan posttest hasil belajar kognitif siswa dengan penerapan model pembelajaran kooperatif tipe The Power of Two kelas $\mathrm{XI}_{7}$ SMA. Negeri 1 Sungguminasa pada materi Sistem Ekskresi. Nilai pretest dengan penerapan model pembelajaran kooperatif tipe The Power of Two yakni dengan jumlah 40 siswa tidak ada siswa yang berada pada kategori nilai sangat tinggi, 27 siswa yang berada pada nilai kategori tinggi, dan pada kategori sedang ada 7 siswa yang berada pada kategori tersebut, pada kategori rendah ada 6 siswa yang berada pada kategori ini dan kategori sangat rendah tidak ada siswa yang berada pada kategori tersebut. Nilai posttest dengan penerapan model pembelajaran kooperatif tipe The Power of Two ada 28 siswa yang berada pada kategori sangat tinggi, pada kategori nilai tinggi ada 11 siswa, pada kategori sedang tidak terdapat siswa pada kategori ini, pada kategori rendah ada 1 siswa yang berada pada kategori tersebut, dan pada ketegori sangat rendah tidak ada siswa pada kategori ini dengan persentase $0 \%$.

Hasil analisis deskriptif nilai pretest dan posttest hasil belajar kognitif siswa yang diperoleh pada materi sistem ekskresi dengan penerapan model pembelajaran kooperatif tipe Make a Match dan The Power of Two dapat dilihat pada Tabel 4.11

Tabel 4.11 Hasil Analisis deskriptif Nilai Pretest dan Posttest Hasil Belajar Kognitif Siswa dengan Penerapan Model Pembelajaran Kooperatif Tipe Make a Match dan The Power of Two.

\begin{tabular}{|l|l|l|l|l|l|}
\hline \multirow{4}{*}{ NO } & \multirow{3}{*}{ Statistik } & \multicolumn{2}{|c|}{$\begin{array}{c}\text { Kooperatif Make } \\
\text { a Match }\end{array}$} & \multicolumn{2}{|c|}{$\begin{array}{c}\text { Kooperatif The } \\
\text { Power of Two }\end{array}$} \\
\cline { 3 - 6 } & Pretest & Posttest & $\begin{array}{c}\text { Prete } \\
\text { st }\end{array}$ & Posttest \\
\hline
\end{tabular}

\begin{tabular}{|l|l|c|c|c|c|}
\hline 1. & Sampel & 40 & 40 & 40 & 40 \\
\hline 2. & $\begin{array}{l}\text { Nilai } \\
\text { Maxim } \\
\text { um }\end{array}$ & 70 & 95 & 72,50 & 97,50 \\
\hline 3. & $\begin{array}{l}\text { Nilai } \\
\text { Minim } \\
\text { um }\end{array}$ & 32,50 & 50 & 40 & 50 \\
\hline 4. & $\begin{array}{l}\text { Rata- } \\
\text { rata }\end{array}$ & 53,20 & 86,33 & 58,25 & 91,50 \\
\hline
\end{tabular}

(Sumber: Arikunto, 2007)

Data pada Tabel 4.11 menunjukkan nilai pretest dan posttest hasil belajar siswa kelas $\mathrm{XI}_{6}$ dan kelas $\mathrm{XI}_{7}$ SMA. Negeri 1 Sungguminasa dengan model pembelajaran kooperatif tipe Make a Match dan The Power of Two pada materi sistem ekskresi, nilai pretest dan potstest siswa dengan penerapan model pembelajaran kooperatif tipe Make a Match dengan 40 jumlah sampel, nilai maximum pretest sebesar 70 dan nilai maksimum posttest sebesar 95 . Nilai minimum pretest sebesar 32,5 dan nilai minimum posttest sebesar 50. Rata-rata nilai pretest yaitu 53,2 dan untuk posttest yaitu 86,33, sedangkan untuk model pembelajaran kooperatif tipe The Power of Two yakni nilai pretest dan posttest hasil belajar siswa kelas $\mathrm{XI}_{7}$ SMAN 1 Sungguminasa dengan penerapan model pembelajaran kooperatif tipe The Power of Two pada materi sistem ekskresi, dengan 40 jumlah sampel, nilai maximum pretest sebesar 72,5 dan nilai posttest menjadi 97,5. Nilai minimum pretest sebesar 40 dan nilai minimum posttest menjadi 50, dan rata-rata nilai pretest yaitu 58,25 menjadi 91,50 nilai posttest.

Nilai hasil belajar biologi siswa diperoleh dari hasil pemberian tes dengan menggunakan instrumen Tes Hasil Belajar (THB) berupa butir soal pilihan ganda terdiri dari 40 jumlah soal. Penyusunan tes hasil belajar (THB) yang diberikan kepada siswa harus bisa mengukur penguasaan siswa terhadap materi setelah proses pembelajaran berlangsung. Apabila nilai hasil belajar biologi siswa dikelompokkan dalam kategori tuntas dan tidak tuntas maka diperoleh deskripsi nilai hasil belajar dapat dilihat pada Tabel 4.12.

Tabel 4.12 Persentase Ketuntasan Hasil Belajar Kognitif

Siswa dengan Penerapan Model Pembelajaran Kooperatif Tipe Make a Match dan The Power of Two.

\begin{tabular}{|c|c|c|c|c|c|}
\hline \multirow[t]{2}{*}{ No } & \multirow{2}{*}{$\begin{array}{c}\text { Katego } \\
\text { ri }\end{array}$} & \multicolumn{2}{|c|}{$\begin{array}{c}\text { Kooperatif } \\
\text { Tipe Make a } \\
\text { Match }\end{array}$} & \multicolumn{2}{|c|}{$\begin{array}{c}\text { Kooperatif tipe } \\
\text { The Power of } \\
\text { Two }\end{array}$} \\
\hline & & $\begin{array}{c}\text { Frekuen } \\
\text { si }\end{array}$ & $(\%)$ & Frekuensi & $(\%)$ \\
\hline 1. & Tuntas & 37 & 85 & 38 & 90 \\
\hline 2. & $\begin{array}{l}\text { Tidak } \\
\text { tuntas }\end{array}$ & 3 & 15 & 2 & 10 \\
\hline
\end{tabular}

Tabel 4.12 menunjukkan ketuntasan hasil belajar siswa kelas $\mathrm{XI}_{6}$ dan $\mathrm{XI}_{7}$ dengan penerapan model pembelajaran kooperatif tipe Make a Match dan The Power of Two. Siswa dengan penerapan model pembelajaran kooperatif Make a Match, kategori tuntas sebanyak 37 siswa dengan persentase $85 \%$ dan kategori tidak tuntas sebanyak 3 siswa dengan persentase $15 \%$, 
Sedangkan untuk kelas dengan penerapan model pembelajaran kooperatif tipe The Power of Two. Kategori tuntas sebanyak 38 siswa dengan persentase $90 \%$, dan kategori tidak tuntas sebanyak 2 siswa dengan persentase $10 \%$. Kriteria ini mengacu pada syarat ketuntasan belajar yakni ketuntasan secara individual apabila mencapai nilai minimal 70 dan secara klasikal $85 \%$ siswa mencapai ketuntasan minimum (KKM) berdasarkan KTSP di SMA Negeri 1 Sungguminasa yaitu 70.

Analisis statistik inferensial digunakan untuk menguji hipotesis penelitian dengan uji-t. Sebelum pengujian hipotesis terlebih dahulu dilakukan pengujian dasar-dasar analisis, yakni uji normalitas dan uji homogenitas.

1. Uji normalitas data hasil belajar biologi siswa

Uji normalitas ini dilakukan untuk mengetahui apakah data berasal dari populasi yang berdistribusi normal. Pengujian normalitas data hasil belajar menggunakan sistem Statistical Package for Social Sciense (SPSS) versi 17.0. Data hasil belajar dari populasi akan berdistribusi normal apabila sig(2-tailed) $>$ $\alpha$ dengan taraf nyata $\alpha=0,05$ model pembelajaran kooperatif tipe Make a Match dan The Power of Two setelah dilakukan analisis data diperoleh nilai sig (2tailed) $=0,208>\alpha=0,05$ yang berarti bahwa kelas dengan penerapan model pembelajaran kooperatif Make a Match dan The Power of Two berasal dari populasi yang berdistribusi normal.

2. Uji homogenitas

Pengujian homogenitas data hasil belajar dengan menggunakan sistem Statistical Package for Social Science (SPSS) versi 17.0, model pembelajaran kooperatif Make a Match dan The Power of Two setelah dilakukan analisis data diperoleh nilai sig-hitung $_{\text {- }}=0,282>$ sig-tabel $(\alpha)=0,05$. Simpulkan bahwa kelas dengan penerapan model pembelajaran kooperatif Make a Match dan The Power of Two memiliki varians yang sama atau homogen.

3. Uji hipotesis

Uji Hipotesis (menggunakan uji t), dilakukan untuk mengetahui apakah terdapat perbedaan hasil belajar antara kedua model yang digunakan terhadap hasil belajar siswa. Data untuk uji hipotesis diolah dengan analisis program Statistical Package for Social Sciense (SPSS) versi 17.0. Hasil belajar biologi siswa menunjukkan bahwa sig-hitung $(0,01)<\operatorname{sig}$. $\alpha(0,05)$ yang berarti Ho ditolak, $\mathrm{H}_{1}$ diterima, ini berarti terdapat perbedaan hasil belajar yang signifikan antara kelas dengan penerapan model pembelajaran kooperatif tipe Make a Match dengan The Power of Two. Jadi dapat diasumsikan bahwa kelas The Power of Two lebih berpengaruh secara signifikan terhadap peningkatan nilai hasil belajar biologi siswa jika dibandingkan dengan kelas Make a Match, dapat dilihat dari nilai parameter estimasi kelas dengan penerapan Make a Match -9,025 sedangkan kelas dengan penerapan The Power of Two adalah 0. Nilai parameter estimasi kelas dengan penerapan model kooperatif tipe The Power of Two lebih besar jika dibandingkan kelas dengan penerapan model kooperatif Make a Match $(0>-9,025)$, jadi dapat disimpulkan bahwa nilai hasil belajar biologi siswa dengan penerapan The Power of Two lebih tinggi 9,025 satuan jika dibandingkan dengan kelas Make a Match. Analisis deskriptif digunakan untuk menganalisis data dengan cara menggambarkan atau mendeskripsikan data yang telah terkumpul. Berdasarkan nilai hasil belajar afektif dengan penerapan model pembelajaran kooperatif tipe make a match dan the power of two dapat dilihat pada tabel 4.16.

Apabila Tabel 4.16 ditampilkan dalam bentuk histogram, maka distribusi frekuensi dan persentase nilai afektif siswa dengan penerapan model pembelajaran kooperatif tipe Make a Match dan The Power of Two dapat dilihat pada Gambar menganalisis data dengan cara menggambarkan atau mendeskripsikan data yang telah terkumpul. Berdasarkan nilai hasil belajar afektif dengan penerapan model pembelajaran kooperatif tipe make a match dan the power of two dalam bentuk histogram, maka distribusi frekuensi dan persentase nilai afektif siswa

Penerapan model pembelajaran kooperatif tipe Make a Match paling tinggi sebanyak 35 siswa dengan persentase $85 \%$ yakni berada pada kategori baik sedangkan untuk penerapan model pembelajaran kooperatif The Power of Two paling tinggi sebanyak 31 siswa dengan persentase $75 \%$ yakni berada pada kategori baik. Paling rendah untuk penerapan model pembelajaran kooperatif tipe Make a Match berada pada kategori kurang dan sangat kurang, tidak ada siswa yang berada pada kategori tersebut sama halnya dengan penerapan model pembelajaran kooperatif The Power of Two juga tidak ada siswa yang berada pada kategori tersebut yakni kategori kurang dan sangat kurang. Analisis deskriptif yang diperoleh dengan penerapan model pembelajaran kooperatif tipe Make a Match dan The Power of Two pada materi sistem ekskresi kelas $\mathrm{XI}_{6}$ dan $\mathrm{XI}_{7}$ dapat dilihat pada Tabel 4.17. Analisis statistik inferensial digunakan untuk menguji hipotesis penelitian dengan ujit. Sebelum pengujian hipotesis terlebih dahulu dilakukan pengujian dasar-dasar analisis, yakni uji normalitas dan uji homogenitas.Uji normalitas data hasil belajar biologi siswa. Uji normalitas ini dilakukan untuk mengetahui apakah data berasal dari populasi yang berdistribusi normal. Pengujian normalitas data hasil belajar menggunakan sistem Statistical Package for Social Sciense (SPSS) versi 17.0. Data hasil belajar dari populasi akan berdistribusi normal apabila sig(2-tailed) $>$ $\alpha$ dengan taraf nyata $\alpha=0,05$ model pembelajaran Make $a$ Match dan The Power of Two. Penerapan model pembelajaran kooperatif tipe Make a Match dan The Power of Two setelah dilakukan analisis data diperoleh nilai sig $(2$-tailed $)=0,208>\alpha=0,05$ yang berarti bahwa kelas dengan penerapan model pembelajaran kooperatif Make a Match dan The Power of Two berasal dari populasi yang berdistribusi normal.

1. Uji homogenitas

Pengujian homogenitas data hasil belajar dengan menggunakan sistem Statistical Package for Social Sciense (SPSS) versi 17.0, diperoleh nilai signifikansi hitung homogenitas penerapan model pembelajaran kooperatif Make a Match dan The Power of Two setelah dilakukan analisis data diperoleh nilai $\operatorname{sig}_{\text {-hitung }}=0,263>$ 
sig-tabel $(\alpha)=0,05$. Simpulkan bahwa kelas dengan penerapan model pembelajaran kooperatif Make a Match dan The Power of Two memiliki varians yang sama atau homogen.

2. Uji hipotesis

Uji Hipotesis (menggunakan uji t), dilakukan untuk mengetahui apakah terdapat perbedaan rerata nilai hasil belajar afektif siswa dengan penerapan model pembelajaran kooperatif tipe Make a Match dan The Power of Two pada materi sistem ekskresi siswa kelas $\mathrm{XI}_{6}$ dan $\mathrm{XI}_{7}$, hasil analisis statistik inferensial menunjukkan nilai signifikansi afektif sebesar $0,021<\alpha$ $=0,05$, ini berarti bahwa terdapat perbedaan nilai afektif yang signifikan antara kelas dengan penerapan model pembelajaran kooperatif Make a Match dengan penerapan model pembelajaran kooperatif tipe The Power of Two.

\section{SIMPULAN}

Berdasarkan hasil analisis data dan diskusi, dapat disimpulkan sebagai berikut. Terdapat perbedaan yang signifikan hasil belajar kognitif pada materi sistem ekskresi antara siswa dengan penerapan model pembelajaran kooperatif Make a Match dan siswa dengan penerapan model pembelajaran kooperatif The Power of Two dengan skor nilai pada model pembelajaran kooperatif tipe The Power of Two berada pada kategori sangat tinggi. Terdapat perbedaan yang signifikan hasil belajar afektif pada materi sistem ekskresi antara siswa dengan penerapan model pembelajaran kooperatif Make a Match dan siswa dengan penerapan model pembelajaran kooperatif tipe The Power of Two dengan skor nilai pada model pembelajaran kooperatif Tipe Make a Match berada pada kategori tinggi. Terdapat perbedaan yang signifikan hasil belajar psikomotorik pada materi sistem ekskresi antara siswa dengan penerapan model pembelajaran kooperatif Make a Match dan siswa dengan penerapan model pembelajaran kooperatif The Power of Two dengan skor nilai pada model pembelajaran kooperatif tipe Make a Match berada pada kategori tinggi. Saran yang dapat penulis kemukakan sehubungan dengan hasil penelitian ini adalah sebagai berikut. Bagi guru disarankan dapat menerapkan model pembelajaran kooperatif tipe Make a Match dan The Power of Two sebagai salah satu alternatif dalam melaksanakan proses pembelajaran di sekolah untuk meningkatkan hasil belajar siswa. Mengingat pada penelitian ini, cukup baik diharapkan untuk para peneliti selanjutnya lebih memperhatikan keefektifan waktunya.

\section{DAFTAR PUSTAKA}

Anderson \& Krathwohl. 2010. Pembelajaran Pengajaran dan Asessmen. Yogyakarta: Pustaka Belajar.

Anwar. 2010. Perencanan Sistem Pembelajaran Kurikulum Tingkat Satuan Pendidikan. Bandung: Alfabeta.

Arends, R. 2008. Learning to Teach Buku 2. Yogyakarta: Pustaka.

Arikunto. 2007. Dasar-Dasar Evaluasi Pendidikan Edisi Revisi. Jakarta: PT Bumi Aksara.
Arzaqi. 2012. Peningkatan Motivasi dan Hasil Belajar Melalui Penerapan Model Pembelajaran Kooperatif The Power of Two

Arsyad, A. 2010. Media Pembelajaran. Jakarta: Raja Grafindo Persada.

Aryulina, D. 2007. Biologi 2 SMA. Jakarta: Esis.

Azwar. 1995. Sikap Manusia Teori dan Pengukurannya. Yogyakarta: Pustaka Belajar.

Ahmad. 2010. Hubungan Antara Model Kooperatif pada hasil belajar kognitif di Universitas Putra Malaysia (Vol. 3 No. 2 Juli 2011). Jurnal (diterbitkan terjemahan). Selangor: Universitas Putra Malaysia. (http://www.mscser.org/ jesjournal diakses 12 April 2014).

Campbell, N.A, J.B Reece. 2002. Biologi Jilid III. Jakarta: Erlangga.

Dahar, R, W. 1996. Teori-Teori Belajar. Jakarta: Erlangga.

Daigo, R. 2012. Perbandingan Make a Match dan The Power of Two: Studi Hubungan (Vol 3 Edisi 4 Maret 2012). Jurnal (diterbitkan) Allahabad: SS Khanna. (http: // www.irsj.net diakses 12 April 2014).

Darso. 2011. Guru Profesional Implementasi Kurikulum Tingkat Satuan Pendidikan dan Sukses dalam Sertifikasi Guru. Jakarta: PT Raja Grafindo.

Daryanto. 2001. Evaluasi Pendidikan. Jakarta: Rineka Cipta.

Departemen Pendidikan Nasional. 2008. Direktorat Jenderal Manajemen Pendidikan Dasar dan Menengah. Direktorat Pembinaan Sekolah.

Dimyati \& Mudjiono. 2009. Belajar dan Pembelajaran. Jakarta: Rineka Cipta.

Eggen. 2012. Strategi dan Model Pembelajaran Mengajarkan Konten dan Keterampalin Berpikir. Jakarta: PT Indeks.

Haling. 2007. Belajar dan Pembelajaran. Makassar: Badan Penerbit UNM.

Hudoyo, H. 1990. Strategi Belajar Mengajar. Malang: IKIP Malang.

Huda. 2011 Pengaruh Penggunaan Tipe Kooperatif Make a Match dan The Power of Two Materi Sistem Reproduksi di SMA Kartika Candra, Jurnal Pendidikan Siswa (online). Di akses 21 Maret 2014.

Ibrahim. 2009. Pembelajaran Kooperatif. Surabaya: UNESA

Ibrahim. 2000. Pembelajaran Kooperatif Pusat Sains dan Matematika Sekolah Program Pasca Sarjana Unesa. Surabaya: University Press.

Isjoni. 2013. Pembelajaran Kooperatif. Yogyakarta: Pustaka Pelajar.

Jati, H \& Inayah, N. 2011. Peningkatan Keaktivan dalam Prestasi Belajar Peserta Didik Melalui Teknik Pembelajaran Mencari Pasangan (Make a Match) Di SMK Negeri 1 Sedayu Tahun Ajaran 2010/2011, (online), (http://staff.uny.ac.id/sites/default/132231621/, Diakses pada tanggal 30 Januari 2014.

Jumriah. 2009. Peningkatan Hasil Pembelajaran Biologi Melalui Model Pembelajaran Kooperatif Make a Match siswa kelas X SMA 4 Makassar Jurnal 
Cakrawala Kependidikan, (online), Vol. 6, No. 2, (http://jurnal.untan.ac.id/index.php/jckrw/article/vie w/306, Diakses 12 April 2014).

Johnson. 2002. Media Pembelajaran. Bandung: PT Citra Aditya bakti.

Lie, A. 2004. Cooperatif Learning Mempratekkan Cooperative Learning di Ruang-Ruang Kelas. Jakarta: Garasindo.

Muhayang. 2010. Penggunaan Metode the Power of Two Rangkaian Listrik DC dalam Meningkatkan Aktivitas dan Pemahaman Konsep Rangkaian Listrik DC Siswa SMA Negeri 5 Pare-Pare. Tesis. Diterbitkan. Makassar:PPs Universitas Negeri Makassar.

Mardapi, D., Kumaidi, Badrun,K. 2011. Pengembangan Instrumen Pengukur Hasil Belajar Afektif. Jurnal

Mulyasa, E. 2003.Kurikulum Berbasis Kompetensi. Bandung: Remaja Rosdakarya.

Muslich. 2007a. KTSP Pembelajaran Berbasis Kompetensi dan Kontekstual. Jakarta: PT. Bumi Aksara.

Ningrum, R. 2008. Keefektifan Model Pembelajaran Kooperatif Tipe Make a Match Melalui Pemamfaatan LKS terhadap Hasil Belajar biologi Sub Pokok Bahasan keanegaragaman hayati VII SMPN 11 Bandung .(Online).(http://digilib.unnes.ac.id/gsdl/collect/skri psi/archives/HASHI2e3/7ad3118f6.dir.doc.pdf).Dia kses tanggal 12 April 2014.

Nurhayati, B. 2011. Strategi Belajar Mengajar. Makassar: Badan Penerbit UNM.

Neneng. 2010. Penerapan Model The Power of Two untuk Meningkatkan Kompetensi Siswa di
Kalimantanl,(online), Vol. $\quad 24, \quad$ No.2 (http://jurnal.untan.ac.id/index.php/jgmm/article/vie w/252, Diakses 12 April 2014).

Prawirohartono, S. 2007. Sains Biologi 2. Jakarta: Bumi Aksara.

Purwanto. 2009. Evaluasi Hasil Belajar. Yogyakarta: Pustaka Belajar.

Riyana. 2007. Media Pembelajaran. Bandung: CV Wacana Prima.

Rohendi, D \& Waslaluddin. 2010. Penerapan Cooperatif Learning Tipe Make a Match Untuk Meningkatkan Hasil Belajar Siswa Kelas VII dalam Pembelajaran Teknologi Informasi dan Komunikasi, (online), Vol.3 dan No.1 (http:/file.upi.edu/direktori/jurnal/pendidik an, Diakses pada tanggal 30 Desember 2014).

Rusman. 2010. Model-Model Pembelajaran Mengembangkan Profesionalisme Guru. Jakarta: PT. Raja Grafindo Persada.

Sardiman, A.M. 2004a. Interaksi dan Motivasi Belajar Mengajar. Jakarta: Raja Grafindo Persada.

Sanjaya,W. 2006a. Strategi Pembelajaran. Jakarta: PT Kencana.

Slameto. 2003. Belajar dan Faktor-Faktor yang Mempengaruhinya. Jakarta: Bina Statistik.

Slavin. 2010. Cooperative Learning. Bandung: PT Nusa Media.

Soemanto, W. 1997. Psikologi Pendidikan. Jakarta: Bina Aksara.

Solihatin, Etin dan Raharjo. 2007. Cooperative Learning Analisis Model Pembelajaran IPS. Jakarta: PT Bumi Aksara. 